\title{
Comparison of Quality of Labor Analgesia by NPRS Score Upon Single Dose Intrathecal Labor Analgesia Between Bupivacaine With Adjuvants (Fentanyl And Dexmedetomidine) And Bupivacaine With Adjuvants (Fentanyl And Morphine): A Randomized Comparative Double Blind Study
}

Dr. Gian Chauhan ${ }^{1}$, Dr. Kartik Syal ${ }^{2}$, Dr. Rajeev Sood ${ }^{3}$,Dr. Geetika Gupta Syal ${ }^{4}$, Dr. Sanjay Rathod ${ }^{5}$, Dr. Rajeev Bansal ${ }^{6} *$, Dr. Manoj Maitan $^{7}$, Dr. AnshitAbhi Pathania ${ }^{8}$, Dr. Anu Shree Bansal ${ }^{9}$,Dr. Madhav Verma ${ }^{10}$, Dr. Sijo ${ }^{11}$ \& Dr. Amit Sachdeva ${ }^{12}$

${ }^{1}$ Professor, ${ }^{2}$ Associate Professor, ${ }^{6,10}$ Junior Resident, ${ }^{7}$ Senior Resident Department of Anaesthesiology, ${ }^{3}$ Professor, ${ }^{4}$ Assistant Professor, ${ }^{5}$ Junior Resident Department of obstetrics \& gynaecology, ${ }^{8}$ Assistant Professor, Department of Anaesthesiology SLBSMC Mandi (Himachal Pradesh), ${ }^{9}$ Research Scholar, Kurukshetra (Haryana), ${ }^{11}$ Consultant Anesthesiologist, Elite Mission Hospital, Thrissur, Kerala, ${ }^{12}$ Senior Resident, Department of Community Medicine Indira Gandhi Medical College, Shimla, India

Article History

Received: 28.08.2020

Accepted: 13.09 .2020

Published: 30.09 .2020

Journal homepage:

https://www.easpublisher.com/easjacc

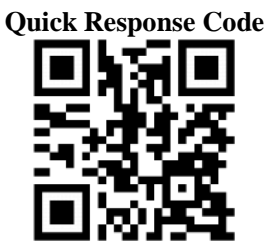

Abstract: Background: Intrathecal analgesics using (ITA) local anesthetics and adjuvants like narcotics are safe and effective alternative to epidural anesthesia. The objective of the study is toassess and compare quality of labor analgesia through NPRS Score upon single dose ITA between bupivacaine with adjuvants (fentanyl and dexmedetomidine) and bupivacaine with adjuvants (fentanyl and morphine).Material \& Methods: The present study was a prospective, randomized and double blinded controlled study.120 parturients allocated into two equal groups $\left(G_{-}{ }_{D} \& G_{-}{ }_{M}\right)$ of 60 patients using block Randomization Technique. Group $G_{-}^{-}$received Bupivaciane, Fentanyl \&Dexmedetomedine while $G_{-}{ }_{M}$ received Bupivaciane, Fentanyl \& Morphine. Quality of analgesia was assessed through NPRS Scale and and analyzed using Epi Info V7.Results: Difference in mean NPRS score between both $\operatorname{Group}(\boldsymbol{G}$. D) and $\operatorname{Group}\left(\boldsymbol{G}_{-\boldsymbol{M}}\right)$ was found to be non- significant at baseline as well as at various time interval till 5 hours. At 0 minutesi.e.the mean NPRS was comparable $(\mathrm{p}>.05)$ in both the groups, $\left(8.65 \pm 0.48 \operatorname{in} \operatorname{Group}\left(\boldsymbol{G}_{-\boldsymbol{M}}\right)\right.$ and $8.58 \pm 0.49 \operatorname{in} \operatorname{Group}(\boldsymbol{G}$. $\left.{ }_{D}\right)$ respectively).After 3 minutes Itdecreased to $3.03 \pm 0.18$ in $\operatorname{Group}\left(\boldsymbol{G}_{-\boldsymbol{M}}\right)$ and $3.10 \pm$ 0.35 minutes inGroup $\left(\boldsymbol{G}_{-\boldsymbol{D}}\right)$ respectively,however itremained less than $5(3.05 \pm 0.229$ inGroup $\left(\boldsymbol{G}_{-\boldsymbol{M}}\right)$ and $3.12 \pm 0.331$ inGroup $\left(\boldsymbol{G}_{-\boldsymbol{D}}\right)$ respectively till 4 hoursof intrathecal injection. Further itincreased to $4.75 \pm 0.50 \mathrm{inGroup}\left(\boldsymbol{G}_{-\boldsymbol{M}}\right)$ and $5.00 \pm 0.00 \mathrm{inGroup}(\boldsymbol{G}$. $\left.{ }_{D}\right)$ respectivelybut the mean NPRS was comparable ( $\left.p>.05\right)$ in both the groups. Conclusion: we found that intrathecallabour analgesia is an effective and safe mode of analgesia. The mean NPRS score remained less than 5 in both the groups till 4.5 hours and was comparable throughout.

Keywords:NPRS Scale, Intrathecal labor analgesia Bupivaciane, Fentanyl, Dexmedetomedine, Morphine.

Copyright (C) 2020 The Author(s): This is an open-access article distributed under the terms of the Creative Commons Attribution 4.0 International License (CC BY-NC 4.0) which permits unrestricted use, distribution, and reproduction in any medium for non-commercial use provided the original author and source are credited.

\section{INTRODUCTION}

Perception of pain by a laboring female is a dynamic process that involves both peripheral and central mechanisms. There are many factors that have an influence on the degree of pain experienced by a woman during labor, including emotional support to the parturient during labor-psychological preparation, past experiences of labor pains, the patient's expectation of labor and induction and augmentation of labor (Alleemudder, D. I. et al .,2015; \& Lynch, L. 2014).
The ideal technique for labor analgesia should provide rapid, effective, economical and safe pain relief for all stages of labor without compromising fetal vital physiology and wellbeing. An ideal technique would leave the mother awake, alert, comfortable with preserved ability to ambulate and bear down throughout the labor (Minty, R. G. et al., 2007).

Intrathecal analgesics using local anaesthetics and adjuvants like narcotics are safe and effective 
alternative to epidural anaesthesia especially in rural and peripheral areas where epidural catheterization may not be possible (Minty, R. G. et al ., 2007).

The NPRS is a segmented numeric version of the visual analog scale (VAS) in which a respondent selects a whole number ( $0-10$ integers) that best reflects the intensity of his/her pain. The common format is a horizontal bar or line. Similar to the VAS, the NPRS is anchored by terms describing pain severity extremes. It is a uni-dimensional measure of pain intensity NPRS Scales have shown high correlations with other painassessment tools in several studies (Haefeli, M., \&Elfering, A. 2006; \&Numeric_Pain_Rating_Scalehttps://www.physiopedia.com).

A very few studies have been done on ITA and its correlation with NPRS scale in laboring patients especially in this hilly state where epidural analgesia is not feasible in most of the institutes (AbdElBarr, T. et al ., 2014; Yeh, H. M. et al ., 2001; Hess, P. E. et al ., 2003; \&Younes, M. 2017).Our study evaluates the quality of analgesia by NPRS scale when dexmedetomidine was given intrathecally with hyperbaric $0.5 \%$ bupivacaine and fentanyl. In view of previous studies, our study also compared the intrathecal morphine with dexmedetomidine as an adjuvant.

\section{Materials ANd Methods}

The present study was a prospective, randomized and double blinded controlled study, done with the objective To assess and compare quality of labor analgesia through NPRS Score upon giving single dose intrathecallabour analgesia between bupivacaine with adjuvants (fentanyl and dexmedetomidine) and bupivacaine with adjuvants (fentanyl and morphine)in a period of one year from $1^{\text {st }}$ July, 2018 to $30^{\text {th }}$ June, 2019. The study was conducted after obtaining the ethical committee clearance and informed consent from the parturient by department of Anesthesia \&Department of Obstetrics and Gynecology at Kamla Nehru State Hospital for Mother and Child, IGMC, Shimla.

Anticipating minimum of $20 \%$ decrease in NPRS Score at the time of delivery considering significance of $95 \%\{\alpha 0.05\}$ and $80 \%$ Power of study $\left\{\begin{array}{ll}\beta & 0.2\end{array}\right.$, we had undertaken this study in 120 patients. Double blind randomization was done to allocate 120 parturient. Fulfilling the inclusion criteria, they were allocated into two equal groups of 60 patients using computerized block Randomization Technique.

Technique of Anesthesia in both groups was

\begin{tabular}{|c|c|}
\hline Group $\left(\mathbf{G}_{\text {-D }}\right)$ :received Single dose of Intrathecal analgesia:- & $\begin{array}{l}\begin{array}{l}\text { Group }\left(\mathbf{G}_{-\mathbf{M}}\right) \text { :received } \\
\text { analgesia:- }\end{array}\end{array}$ \\
\hline $0.5 \mathrm{ml}$ of $0.5 \%$ bupivacaine heavy $(2.5 \mathrm{mg})$ with & $0.5 \mathrm{ml}$ of $0.5 \%$ bupivacaine $0.5 \%$ heavy $(2.5 \mathrm{mg})$ with \\
\hline $0.5 \mathrm{ml}$ Fentanyl $(25 \mathrm{mcg})$ and & $0.5 \mathrm{ml}$ fentanyl $(25 \mathrm{mcg})$ and \\
\hline $\begin{array}{l}1 \mathrm{ml} \text { of Dexmedetomedine }(5 \mathrm{mcg}) \quad[50 \mathrm{mcg} / \mathrm{ml} \\
\text { Dexmedetomedinediluted in NS to make a concentration of } \\
5 \mathrm{mcg} / \mathrm{ml}]\end{array}$ & $\begin{array}{l}\text { 1ml Morphine }(250 \mathrm{mcg})[15 \mathrm{mg} / \mathrm{ml} \text { diluted to make } 250 \\
\mathrm{mcg} / \mathrm{ml}] ;\end{array}$ \\
\hline The total injectate : $2 \mathrm{ml}$ & The total injectate $: 2 \mathrm{ml}$ \\
\hline
\end{tabular}

On admission to labour room detailed history and examination was undertaken. Parturient with cervical dilatation of 4-6 cm was randomly allocated into two groups using sealed envelopes. An anesthetist not involved in the study opened the already coded and sealed envelope for the parturient to pick from. All aseptic precautions were undertaken and the procedure was done in operation theatre.L3-L4 inter-space was identified and 26-27 G spinal needle was introduced median/Para median approach. Correct placement of spinal needle in subarachnoid space was confirmed by free flow of cerebrospinal fluid and coded drug was injected. Patient was kept in supine position for 10 min, and then allowed to ambulate with assistant.

Quality of analgesia was assessed by 11-point numeric NPRS score. In a Numerical pain Rating Scale (NPRS), patients were asked to give the number between 0 and 10, that fits best to their pain intensity. Zero usually represents 'no pain at all' whereas the upper limit represents 'the worst pain ever possible (Haefeli, M., \& Elfering, A. 2006; \& Numeric_Pain_Rating_Scale https://www.physio-pedia.com).'

Data was entered in MS Excel and analyzed using Epi Info Software Version 7. For qualitative variables frequency/percentage was calculated while for quantitative variables mean/ standard deviation was calculated. Appropriate statistical tests like paired $\mathrm{t}$-test / Chi Square was applied for the measure of association. $\mathrm{P}$ value $<0.05$ was taken as statistically significant. 


\section{RESULTS}

The two groups were comparable in terms of patients Socio-demographic characteristics (age, parity, period of gestation, etc.)

Table- 1: Distribution of study participants according to Age and POG

\begin{tabular}{|c|c|c|c|c|c|}
\hline & $\begin{array}{l}\operatorname{Group}\left(G_{-D}\right) \\
(\mathrm{N}=60)\end{array}$ & Percentage & $\begin{array}{l}\operatorname{Group}\left(G_{-M}\right) \\
(\mathrm{N}=60)\end{array}$ & Percentage & $P$ value \\
\hline \multicolumn{6}{|l|}{ Age } \\
\hline$\leq 20$ & 3 & $5 \%$ & 4 & $6.7 \%$ & \\
\hline $21-25$ & 30 & $50 \%$ & 26 & $43.3 \%$ & 0.853 \\
\hline $26-30$ & 22 & $36.7 \%$ & 23 & $38.3 \%$ & \\
\hline $31-35$ & 5 & $8.3 \%$ & 7 & $11.7 \%$ & \\
\hline Mean age (Years) & \multicolumn{2}{|l|}{$25.48 \pm 3.601$} & \multicolumn{2}{|l|}{$25.82 \pm 3.703$} & 0.618 \\
\hline \multicolumn{6}{|l|}{ POG (weeks) } \\
\hline $37-38^{+6}$ & 17 & $28.3 \%$ & 19 & $31.7 \%$ & \\
\hline $39-40^{+6}$ & 42 & $70 \%$ & 39 & $65 \%$ & 0.757 \\
\hline $41-42$ & 1 & $1.7 \%$ & 2 & $3.3 \%$ & \\
\hline Mean POG (wks) & \multicolumn{2}{|l|}{$39.08 \pm 1.046$} & \multicolumn{2}{|l|}{$39.08 \pm 1.154$} & 1.000 \\
\hline
\end{tabular}

Table 1 showed that the maximum number of parturient in Group $\left(G_{-D}\right)(50 \%)$ and in $\operatorname{Group}(G$. $\left.{ }_{M}\right)(43.3 \%)$ were in age group between $21-25$ years. The mean age in Group $\left(G_{-D}\right)(25.48 \pm 3.601 \mathrm{yr})$ and in Group $\left(G_{-M}\right)(25.82 \pm 3.703 y r)$. Majority of subjects were between $37-40$ weeks i.e. $98.3 \%$ in Group $\left(G_{-D}\right)$ and $96.7 \%$ in Group $\left(G_{-M}\right)$. The mean POG of the parturient which was $39.08 \pm 1.046$ weeks in Group $\left(G_{-D}\right)$ and $39.08 \pm 1.154$ weeks in $\operatorname{Group}\left(G_{-M}\right)$.

Table 2:NPRS (numerical pain rating scale) intergroup comparison

\begin{tabular}{|c|c|c|c|c|c|}
\hline & Group & $\mathbf{N}$ & Mean Score & Std. Deviation & P value \\
\hline \multirow[t]{2}{*}{$\overline{\text { NPRS }_{B L}}$} & $G_{-D}$ & 60 & 8.58 & .497 & .457 \\
\hline & $G_{-M}$ & 60 & 8.65 & .481 & \\
\hline \multirow[t]{2}{*}{ NPRST1 } & $G_{-D}$ & 60 & 8.53 & .503 & .465 \\
\hline & $G_{-M}$ & 60 & 8.60 & .494 & \\
\hline \multirow[t]{2}{*}{ NPRST3 } & $G_{-D}$ & 60 & 3.10 & .354 & 0.198 \\
\hline & $G_{-M}$ & 60 & 3.03 & .181 & \\
\hline \multirow[t]{2}{*}{ NPRS4 } & $G_{-D}$ & 60 & 3.08 & .381 & .346 \\
\hline & $G_{-M}$ & 60 & 3.02 & .390 & \\
\hline \multirow[t]{2}{*}{ NPRS5 } & $G_{-D}$ & 60 & 3.07 & .252 & .475 \\
\hline & $G_{-M}^{-D}$ & 60 & 3.03 & .258 & \\
\hline \multirow[t]{2}{*}{ NPRS10 } & $G_{-D}^{-M}$ & 60 & 3.05 & .341 & 1.000 \\
\hline & $G_{-M}^{-D}$ & 60 & 3.05 & .287 & \\
\hline \multirow[t]{2}{*}{ NPRST20 } & $G_{-D}^{-M}$ & 60 & 3.05 & .287 & 1.000 \\
\hline & $G_{-M}$ & 60 & 3.05 & .341 & \\
\hline \multirow[t]{2}{*}{ NPRST25 } & $G_{-D}$ & 60 & 3.07 & .312 & .563 \\
\hline & $G_{-M}^{-D}$ & 60 & 3.03 & .317 & \\
\hline \multirow[t]{2}{*}{ NPRS30 } & $G_{-D}$ & 60 & 3.10 & .303 & .162 \\
\hline & $G_{-M}$ & 60 & 3.02 & .344 & \\
\hline \multirow[t]{2}{*}{$\mathrm{NPRS}_{60}$} & $G_{-D}$ & 60 & 3.07 & .252 & .736 \\
\hline & $G_{-M}^{-D}$ & 60 & 3.05 & .287 & \\
\hline \multirow[t]{2}{*}{ NPRS1.5H } & $G_{-D}$ & 60 & 3.02 & .129 & .414 \\
\hline & $G_{-M}$ & 60 & 3.05 & .287 & \\
\hline \multirow[t]{2}{*}{ NPRS2H } & $G_{-D}$ & 60 & 3.07 & .252 & .525 \\
\hline & $G_{-M}$ & 60 & 3.03 & .317 & \\
\hline \multirow[t]{2}{*}{ NPRS2.5H } & $G_{-D}$ & 60 & 3.07 & .252 & .761 \\
\hline & $G_{-M}$ & 60 & 3.05 & .341 & \\
\hline \multirow[t]{2}{*}{ NPRS3H } & $G_{-D}$ & 60 & 3.05 & .341 & .136 \\
\hline & $G_{-M}$ & 60 & 2.95 & .387 & \\
\hline \multirow[t]{2}{*}{ NPRS3.5H } & $G_{-D}^{-1 /}$ & 53 & 3.02 & .137 & .206 \\
\hline & $G_{-M}$ & 60 & 3.07 & .252 & \\
\hline \multirow[t]{2}{*}{ NPRS4H } & $G_{-D}$ & 33 & 3.12 & .331 & .334 \\
\hline & $G_{-M}$ & 37 & 3.05 & .229 & \\
\hline \multirow[t]{2}{*}{ NPRS4.5H } & $G_{-D}^{-M}$ & 3 & 5.00 & .000 & . \\
\hline & $G_{-M}$ & 4 & 4.75 & .500 & .391 \\
\hline
\end{tabular}


Table 2 depicted that Difference in mean NPRS score between both $\operatorname{Group}\left(\boldsymbol{G}_{-D}\right)$ and $\operatorname{Group}(\boldsymbol{G}$. $\left.{ }_{M}\right)$ was found to be non- significant at baseline as well as at various time interval till 5 hours. At 0 minutesi.e.the mean NPRS was comparable (p>.05) in both the groups, $\quad\left(8.65 \pm 0.48 \quad\right.$ in $\operatorname{Group}\left(\boldsymbol{G}_{-\boldsymbol{M}}\right)$ and $\quad 8.58 \pm 0.49$ inGroup $\left(\boldsymbol{G}_{-D}\right)$ respectively).After 3 minutes Itdecreased to $3.03 \pm 0.18$ in $\operatorname{Group}\left(\boldsymbol{G}_{-M}\right)$ and $3.10 \pm 0.35$ minutes $\operatorname{in} \operatorname{Group}\left(\boldsymbol{G}_{-D}\right)$ respectively,howeveritremained less than $5 \quad\left(3.05 \pm 0.229 \quad\right.$ inGroup $\left(\boldsymbol{G}_{-\boldsymbol{M}}\right)$ and $\quad 3.12 \pm 0.331$ inGroup $\left(\boldsymbol{G}_{-\boldsymbol{D}}\right)$ respectively till 4 hoursof intrathecal injection. Further itincreased to $4.75 \pm 0.50$ in $\operatorname{Group}(\boldsymbol{G}$. ${ }_{M}$ )and $5.00 \pm 0.00$ inGroup $\left(\boldsymbol{G}_{-\boldsymbol{D}}\right)$ respectivelybut the mean NPRS was comparable (p>.05) in both the groups.

None of the patients of either group delivered in the first 3 hours $(\mathrm{n}=60) .7$ patients delivered after $3 \frac{1}{2}$ hours in $\operatorname{Group}\left(\boldsymbol{G}_{-\boldsymbol{D}}\right)$ and no patient delivered in $\operatorname{Group}\left(\boldsymbol{G}_{-\boldsymbol{M}}\right)$ after similar time.After 4 hours, 27 patients delivered in $\operatorname{Group}\left(\boldsymbol{G}_{-\boldsymbol{D}}\right)$ and 23 patients delivered in $\operatorname{Group}\left(\boldsymbol{G}_{-M}\right)$. At the end of $41 / 2$ hours 3 patients in $\operatorname{Group}\left(\boldsymbol{G}_{-\boldsymbol{D}}\right)$ and 4 patients in $\operatorname{Group}\left(\boldsymbol{G}_{-\boldsymbol{M}}\right)$ remained undelivered, that is 57 out of $60(95 \%)$ patients delivered in $\operatorname{Group}\left(\boldsymbol{G}_{-\boldsymbol{D}}\right)$ and 56 out of $60(93 \%)$ delivered in $\operatorname{Group}\left(\boldsymbol{G}_{-\boldsymbol{M}}\right)$.

\section{DISCUSSION}

In the present study all the parturient females were evaluated for postoperative analgesia on the basis of NPRS (Numerical Pain Rating Scale) on a scale of 0 to 10,0 being no pain and 10 was worst pain possible. The mean NPRS score between both $\operatorname{Group}\left(G_{-D}\right)$ and $\operatorname{Group}\left(G_{-M}\right)$ was found to be non- significant at baseline as well as at various time interval till 5 hours.

The result of our study coincides with the study by AbdElBarr $\mathrm{T}$ et al., ${ }^{6}$ onlabour analgesia wherethey observed that the visual analogue scores after 5,15,30, 60, 90, 120, 150 minutesremainedlower in Spinal group that received $3.75 \mathrm{mg}$ hyperbaric bupivacaine $+25 \mu$ gfentanylwith $0.75 \mathrm{ml}$ saline is a good alternativeto epidural analgesia using $4 \mathrm{ml}$ bupivacaine with $4 \mathrm{ml}$ saline and $1 \mathrm{ml}$ fentanyl in relieving labour pains.

In another study by Yeh, H. M.et al .,(2001) in 100 patients, they found that use of intrathecal bupivacaine $2.5 \mathrm{mg}$ and $12.5 \mathrm{ug}$ fentanyl decreased VAS to $1 / 10$ which remained so till end of delivery. This was similar to our findings where we found VAS to be below 4, number which is considered to be comfortable for the patient, during our entire study period.

$$
\begin{aligned}
& \text { HESS et al.,(2003)conducted a study on labour } \\
& \text { analgesia using a small dose of } \\
& \text { spinal bupivacaine/fentanyl alone or in combination } \\
& \text { with a small dose of morphine. Sixty parturients were } \\
& \text { enrolled in this placebo-controlled, double-blinded, }
\end{aligned}
$$

randomized trial. All women received a spinal injection of $12.5 \mu \mathrm{g}$ fentanyl with $2 \mathrm{mg}$ of bupivacaine. The morphine group $(M B F)$ also received $125 \mu \mathrm{g}$ of morphine; the placebo group $(B F)$ received saline. Pain scores were less than 3 of 10 within 10 minutes of injection, lasting for the entire delivery period.

In a study done by Youneset al .,(2017) on IT hyperbaric bupivacaine $0.5 \%$ at a dose of $1 \mathrm{ml}$ plus 25 ug fentanyl 0.5 mlfor labour pain a comparative study with continuous epidural analgesia with bupivacaine showedthatVAS remained $<3$ throughout the observed period i.e. till 150 minutes.

In another studydone by Tshibuyiet al .,(2013)in 98 patients for labour analgesia, they compared two groups; group I had bupivacaine $2.5 \mathrm{mg}$, fentanyl $25 \mathrm{ug}$ and in second group they added morphine $150 \mathrm{ug}$ to this combination. Similar to our findings they also found out that these combination gave effective analgesia in labouring patients lasting for 3 hours, having VAS $<3$ during the entire study period. They also found out that addition of morphine provided more effective VAS in the period after 90 minutes of intrathecal injection.

Mathuret al.,(2017) conducted the prospective study to evaluate the progress of labour and hemodynamic changes in the mother and fetus with intrathecal analgesia using bupivacaine and fentanyl during normal vaginal delivery.GroupSA(n = 30) received an intrathecal injection of $0.5 \%$ hyperbaric bupivacaine $2.5 \mathrm{mg}$ and fentanyl $25 \mu \mathrm{g}$ and compared with Group $C(\mathrm{n}=30)$ who refused to give consent for neuraxial analgesia. T.In their study the mean VAS score never increased to more than 4 till the end of observed period in any group.

Similar to study done by Shah V et al .,(2018) for labour analgesia, Group $A(\mathrm{n}=50)$ patients were administered intrathecaldexmedetomedine in $1 \mathrm{ml}$ normal saline, Group $B(\mathrm{n}=50)$ patients were administeredIntrathecal 20 ugfentanyl in $1 \mathrm{ml}$ of normal saline and in Group $C(\mathrm{n}=50)$ patients were administered5 ugdexmed and 10 ug fentanyl in $1 \mathrm{ml}$ normal saline.Theyfoundthat all patients achieved VASless than 3 after 5 min.

Similar to our studydone by Madishetti, E. R., \&Aasim, S. A. (2018) for labour analgesia( $n=40)$ in each group, GroupD (5 microgram) GroupF (20 microgram), Group DF (dexmed 5 microgram and fentanyl 10microgram) inthedf group. All the patients in three groups had baseline VAS ranged from $7-10$. At 5 minutes, VASscore became less than 3in all three groups .In their study, VAS was recorded every $1 \mathrm{~min}$ for 10 minutesand then every 10 minutes till VAS reached more than 3 . 


\section{CONCLUSION}

Thus to conclude, through our randomised controlled prospective Blind study, we found that intrathecallabour analgesia is an effective and safe mode of analgesia. The mean NPRS score remained less than 5 in both the groups till 4.5 hours and was comparable throughout.

\section{REFERENCE}

1. AbdElBarr, T., Elshalakany, N. A., \&Shafik, Y. M. (2014). Single dose spinal analgesia: Is it a good alternative to epidural analgesia in controlling labour pain?.Egyptian Journal of Anaesthesia, 30(3), 241-246

2. Alleemudder, D. I., Kuponiyi, Y., Kuponiyi, C., McGlennan, A., Fountain, S., \&Kasivisvanathan, R. (2015). Analgesia for labour: an evidence-based insight for the obstetrician. The Obstetrician \&Gynaecologist, 17(3), 147-155.

3. Haefeli, M., \&Elfering, A. (2006). Pain assessment. European Spine Journal, 15(1), S17S24.

4. Hess, P. E., Vasudevan, A., Snowman, C., \& Pratt, S. D. (2003). Small dose bupivacaine-fentanyl spinal analgesia combined with morphine for labor. Anesthesia \& Analgesia, 97(1), 247-252.

5. Lynch, L. (2014). Intrathecal drug delivery systems, Continuing Education in Anaesthesia Critical Care \&Pain.February, 14(1), 27-31.

6. Madishetti, E. R., \&Aasim, S. A. (2018). A Comparative Prospective Study of IntrathecalDexmedetomidine-Fentanyl for Labor Analgesia. Journal of Advanced Medical and Dental Sciences Research, 6(1).
7. Mathur, P., Jain, N., Prajapat, L., Jain, K., Garg, D., \&Khandelwal, V. (2017). Effect of intrathecal labor analgesia using fentanyl $25 \mu \mathrm{g}$ and bupivacaine $2.5 \mathrm{mg}$ on progress of labor. Journal of Obstetric Anaesthesia and Critical Care,7(1), 47.

8. Minty, R. G., Kelly, L., Minty, A., \& Hammett, D. C. (2007). Single-dose intrathecal analgesia to control labour pain: Is it a useful alternative to epidural analgesia?. Canadian Family Physician, 53(3), 437-442.

9. Numeric_Pain_Rating_Scale. Available at: https://www.physiopedia.com/Numeric_Pain_Rating_Scale (Assessed on 13 May 2018)

10. Shah, V. A., Bajaj, M., \&Verma, J. (2018). Randomized Comparative Study of Intrathecal Administration of Dexmedetomidine-Fentanyl for Labour Pain. National Journal of Integrated Research in Medicine, 9(1).

11. Tshibuyi, P. N., Ogutu, O., \&Chokwe, T. M. (2013). Comparative Study on the Efficacy of Two Regimens of Single-Shot Spinal Block for Pain Relief in Women Presenting in Established Labour. East African Medical Journal, 90(1), 1218.

12. Yeh, H. M., Chen, L. K., Shyu, M. K., Lin, C. J., Sun, W. Z., Wang, M. J., ... \& Tsai, S. K. (2001). The addition of morphine prolongs fentanylbupivacaine spinal analgesia for the relief of labor pain. Anesthesia \& Analgesia, 92(3), 665-668.

13. Younes, M., Gamil, K., \&Elgarhy, A. M. (2017). Intrathecal hyperbaric bupivacaine with fentanyl for labor pain control: a comparative study with continuous epidural analgesia with bupivacaine. Ain-Shams Journal of Anaesthesiology, 10(1), 230. 